\title{
Total Synthesis of Isokidamycin
}

\author{
B. Michael O’Keefe, Douglas M. Mans $§$, David E. Kaelin Jr. ${ }^{\dagger}$, and Stephen F. Martin ${ }^{\star}$ \\ Department of Chemistry and Biochemistry, The University of Texas, Austin, TX, 78712
}

\begin{abstract}
The synthesis of isokidamycin, which represents the first total synthesis of a bis-C-aryl glycoside natural product in the pluramycin family, has been completed. The synthesis features the use of a silicon tether as a disposable regiocontrol element in an intramolecular Diels-Alder reaction between a substituted naphthyne and a glycosyl furan and a subsequent $\mathrm{O} \rightarrow \mathrm{C}$-glycoside rearrangement.
\end{abstract}

Kidamycin (1) is a member of the pluramycin class of $C$-aryl glycoside antibiotics that was isolated from Streptomyces phaeoverticillatus and displays a broad range of antibacterial, antifungal and anticancer properties.i Like other pluramycins, 1 binds to DNA, leading to single strand cleavage.ii Kidamycin possesses an angular anthrapyranone tetracyclic core that is adorned with a $\beta$-angolosaminyl $C$-glycoside substituent at $\mathrm{C}(8)$ and an $\alpha-N, N$ dimethylvancosaminyl $C$-glycoside group at C(10).iii Kidamycin (1) is both light and acid sensitive and is easily transformed into isokidamycin (2) upon treatment with acid.iiiariv No doubt owing to their complex structures and labile functionality, none of the bis- $C$ arylglycoside antibiotics of the pluramycin family have succumbed to total synthesis. Indeed, few have even dared to embark on such a challenging enterprise.v

Several years ago we reported a unified strategy for preparing the four major classes of $C$ aryl glycoside antibiotics.vi The approach relies on the ring-opening of glycosyl-substituted oxabicycles that are produced by the Diels-Alder reactions of substituted arynes with glycosyl furans. A significant feature of this novel entry to $C$-aryl glycosides is that it couples the introduction of the $C$-aryl glycoside moiety with the annelation of a new aromatic ring, thereby leading to a rapid increase in complexity. We subsequently applied this method to the syntheses of several $C$-aryl glycoside natural products.vii However, we wished to extend this methodology to the synthesis of a more complex member of the pluramycin family. We now report our efforts in this area that resulted in the total synthesis of isokidamycin (2), the first bis- $C$-arylglycoside antibiotic to be prepared by total synthesis.

The essential elements of our approach to kidamycin are outlined in Figure 1. Given the known propensity for the $N, N$-dimethylvancosamine moiety at $\mathrm{C}(10)$ of $\mathbf{1}$ to suffer epimerization at the anomeric center to give 2 , we favored the late stage introduction of this residue from the advanced intermediate $\mathbf{3}$ using the $O \rightarrow C$-glycoside rearrangement that had been pioneered by Suzuki and had been shown to be applicable to the preparation of some $\alpha$ $C$-aryl glycosides.viii We envisioned that anthrol $\mathbf{3}$ would be accessible from $\mathbf{4}$ by cleavage of the disposable silicon tether, ring-opening of the oxabicycle, and annelation of the

sfmartin@mail.utexas.edu.

\$Current address: Glaxo Smith Kline, 709 Swedeland Rd., King of Prussia, PA 19406

${ }^{\dagger}$ Current address: Merck \& Co., Inc., 126 E. Lincoln Ave., Rahway, NJ 07065

Supporting Information Available: Experimental procedures and spectral data for compounds 2-5, 7, 10, 12, 16, 17, 19, 20, 23, 24, copies of ${ }^{1} \mathrm{H}$ - and ${ }^{13} \mathrm{C}-\mathrm{NMR}$ spectra for all new compounds, and a tabular comparison for synthetic 2 with an authentic sample. This material is available free of charge via the Internet at http://pubs.acs.org. 
substituted pyranone ring. Intermediate $\mathbf{4}$ would then be formed by the pivotal intramolecular naphthyne-furan cycloaddition that would be initiated by reductive dehalogenation of $\mathbf{5}$, which would be assembled via the union of the substituted naphthalene $\mathbf{6}$ and the protected amino glycosyl furan 7.

The preparation of $\mathbf{7}$ began with the Friedel-Crafts alkylation of furan with the known mixture of azidoacetates $\mathbf{9}$,ix which were obtained from commercially available glycal $\mathbf{8}$ and subsequent saponification of the acetate moiety of the intermediate furyl glycoside to deliver 10 in $60 \%$ overall yield. (Scheme 1). A straightforward four-step sequence involving protection of the secondary alcohol in $\mathbf{1 0}$, reduction of the azide, protection of the resultant primary amine, and $N$-methylation gave the carbamate $\mathbf{1 1}$ in $90 \%$ overall yield. The silicon tether, which was to be utilized as the key regiocontrol element in the planned cycloaddition, was then installed by reaction of the lithiated derivative of the glycosyl furan $\mathbf{1 1}$ with chlorodimethylvinylsilane to give 12, and subsequent hydroboration/oxidation delivered $\mathbf{7}$.

The synthesis of the substituted naphthol 6 commenced with $O$-benzylation of the known naphthoquinone 13x (Scheme 2). Sequential bromination and dehydrobromination transformed 13 into 14, which underwent a second bromination and dehydrobromination to provide the dibromonaphthoquinone $\mathbf{1 5}$. Reduction of the quinone moiety and selective methylation of the sterically less hindered hydroxyl group furnished naphthol $\mathbf{6}$ in $90 \%$ yield.

The union of the requisite hydroquinone $\mathbf{6}$ and glycosyl furan $\mathbf{7}$ was achieved via a facile Mitsunobu etherification to give the key intermediate 5 in $92 \%$ yield, thereby setting the stage for the key intramolecular Diels-Alder reaction (Scheme 3). In the event, dropwise addition of $n$-BuLi to a solution of $\mathbf{5}$ in THF at $-25^{\circ} \mathrm{C}$ delivered oxabicycle $\mathbf{4}$ as a mixture of diastereomers in $92 \%$ yield. Subsequent removal of the silicon tether and $O$-methylation of the resultant naphthol gave 16. Treatment of $\mathbf{1 6}$ with TMSOTf induced the opening of the oxabicyclic ring with concomitant cleavage of the $\mathrm{N}$-tert-butyl carbamate protecting group to furnish anthrol $\mathbf{1 7}$ in $85 \%$ yield. Processing of $\mathbf{1 7}$ by reductive $N$-methylation, TIPS protection of the anthrol, chemoselective hydrogenolysis of the phenolic benzyl group,xi ortho-bromination and MOM protection of the intermediate anthrol provided 18 in $47 \%$ overall yield.

At this juncture, it was necessary to annelate a pyranone ring, and we opted for an approach entailing the cyclization of a phenolic acetylenic ketone derived from $\mathbf{1 8}$ (Scheme 4).xii We originally envisioned that 18 might be converted into 19 via a carbonylative cross-coupling reaction that we had developed for transforming hindered aryl halides into acetylenic ketones;xiii however, all attempts to extend this method to the problem at hand were unsuccessful. On the other hand, subjection of $\mathbf{1 8}$ to metal-halogen exchange, followed by trapping of the resultant aryl anion with aldehyde $\mathbf{2 0}$ and oxidation with $\mathrm{BaMnO}_{4}$ furnished ketone 19 in $72 \%$ overall yield. Formation of the pyranone ring was then achieved by the Lewis acid-promoted cyclization of an intermediate vinylogous diethylamide; subsequent removal of the phenolic TIPS protecting group afforded $\mathbf{3}$ in about 50\% overall yield from 19.

The stage was then set for introducing a vancosamine subunit onto $\mathbf{3}$ via a $O \rightarrow C$-glycoside rearrangement. It was first necessary to prepare a suitable glycosyl donor, and we targeted 22 because the protecting group strategy we had adopted was originally designed to enable the simultaneous deprotection of multiple functional groups later in the synthesis. Although there are de novo syntheses of vancosamine derivatives,xiv we elected a more expedient approach that simply entailed degrading vancomycin by straightforward modification of an 
established protocol,xv thereby obtaining the vancosamine donor 22 as a mixture (10:1) of $\alpha$ - and $\beta$-anomers, respectively, in $76 \%$ overall yield (Scheme 5).

We were cognizant of the fact that there were only a few examples of $O \rightarrow C$-glycoside rearrangements that delivered $\alpha-C$-aryl glycosides, because the highly Lewis acidic reaction conditions typically promotes epimerization of the kinetically formed $\alpha$-glycoside to the thermodynamically more stable $\beta$ - $C$-aryl glycoside.vc'xvi In exploratory work using model systems, we experienced some success in intercepting the desired $\alpha$-anomer of a vancosamine-derived $C$-arylglycoside. However, these model studies did not transfer to the real system. Namely, when anthrol $\mathbf{3}$ and the vancosamine donor $\mathbf{2 2}$ were coupled using a number of Lewis acid promoters, the $\beta, \beta$-bis- $C$-aryl glycoside was the major, if not exclusive product. After extensive experimentation and optimization, we discovered that reaction of 3 and 22 in the presence of $\mathrm{Sc}(\mathrm{OTf})_{3}$ as the promoter, followed by $O$-acetylation of the intermediate phenol furnished $\mathbf{2 3}$ in about $\mathbf{8 0 \%}$ overall yield (Scheme 6); none of the desired $\alpha$-anomer was detected. Although the adverse stereochemical outcome of this reaction would not enable us to complete the total synthesis of kidamycin (1), our disappointment was attenuated by the realization that $\mathbf{2 3}$ might serve as a viable precursor of isokidamycin (2).

Removal of the protecting groups from the angolosaminyl and vancosaminyl glycosidic subunits in $\mathbf{2 3}$ proved to be more challenging than we had anticipated because of a number of interfering side reactions involving the multiple functional groups. Eventually, we discovered a series of manipulations that reliably transformed $\mathbf{2 3}$ into the penultimate intermediate $\mathbf{2 4}$ in $39 \%$ overall yield. The sequence commenced with the removal of the $O$ benzyl protecting group in $\mathbf{2 3}$ with $\mathrm{BBr}_{3}$. The $N$-Cbz protecting group was removed with TMSI, the resultant primary amine was reductively methylated, and the phenolic acetate protecting group was cleaved. Removal of the more hindered acetate group on the vancosamine subunit proved to be rather more problematic as the prolonged exposure to base that was required for its cleavage led to rupture of the pyranone ring; however, we discovered that stirring the $O$-acetyl derivative of $\mathbf{2 4}$ in $\mathrm{MeOH}$ for 3 daysxvii cleanly afforded 24. Oxidative demethylation of two methoxy groups on the central ring of the anthracene core of $\mathbf{2 4}$ then delivered isokidamycin (2) in 51\% yield. The synthetic material thus obtained possessed physical properties identical to those reported in the literature and with an authentic sample.iv'xviii

In summary, the synthesis of isokidamycin (2), which represents the first total synthesis of a bis- $C$-aryl glycoside natural product in the pluramycin family, has been completed. The synthesis features an application of our strategy for using silicon tethers as disposable linkers to control the regiochemistry in Diels-Alder reactions of substituted naphthynes and furans in a highly efficient process that couples the formation of a $C$-arylglycoside with the annelation of a new aromatic ring. Although introduction of the vancosaminyl donor did not proceed with the correct stereochemistry, the work of McDonald suggests that the application of $O \rightarrow C$-glycoside rearrangements involving other vancosamine derivatives might lead to a solution to this problem. Further applications of our general approach to complex $C$-aryl glycoside natural products are in progress, and the results of these investigations will be reported in due course.

\section{Supplementary Material}

Refer to Web version on PubMed Central for supplementary material. 


\section{Acknowledgments}

We thank the National Institutes of Health (GM31077), the Robert A. Welch Foundation (F-652) for generous support of this research. We are grateful to Eli Lilly and Abbott Laboratories for their generous gifts of vancomycin $\bullet \mathrm{HCl}$. We also thank Prof. Urs Séquin (Univ. of Basel, Switzerland) for providing authentic samples of $\mathbf{1}$ and $\mathbf{2}$ for comparison. We also thank Yoshitaka Ichikawa (Kyoto University) for the preparation of starting materials.

\section{References}

i. (a) Kanda N. J Antibiot. 1971; 24:599. [PubMed: 5132247] (b) Kanda N, Morihiro K, Asano K. J Antibiot. 1972; 25:553. [PubMed: 4648309]

ii. For a review of the pluramycin antibiotics, see: Hansen MR, Hurley LH. Acc Chem Res. 1996; 29:249.

iii. (a) Furukawa M, Hayakawa I, Ohta G. Tetrahedron. 1975; 31:2989. (b) Furukawa M, Iitaka Y. Acta Crystallogr B. 1980; 36:2270.

iv. Séquin, U. The Antibiotics of the Pluramycin Group (4H-Anthra[1,2-b]pyran Antibiotics). In Progress in the Chemistry of Organic Natural Products; Herz, W., Grisebach, H., Kirby, G. W., and Tamm, C., Eds; Springer-Verlag: New York 1986; 57.

v. (a) Hauser FM, Rhee RP. J Org Chem. 1980; 45:3061. (b) Fei Z, McDonald FE. Org Lett. 2005; 7:3617. [PubMed: 16092833] (c) Fei Z, McDonald FE. Org Lett. 2007; 9:3547. [PubMed: 17691798]

vi. (a) Kaelin DE Jr, Lopez OD, Martin SF. J Am Chem Soc. 2001; 123:6937. [PubMed: 11448205] (b) Martin SF. Pure Appl Chem. 2003; 75:63. (c) Kaelin DE Jr, Sparks SM, Plake HR, Martin SF. J Am Chem Soc. 2003; 125:12994. [PubMed: 14570450]

vii. (a) Apsel B, Bender JA, Escobar M, Kaelin DE Jr, Lopez OD, Martin SF. Tetrahedron Lett. 2003; 44:1075. (b) Chen CL, Martin SF. J Am Chem Soc. 2006; 128:13696. [PubMed: 17044691] (c) Sparks S, Chen C, Martin S. Tetrahedron. 2007; 63:8619. [PubMed: 18728697]

viii. For selected examples of $\mathrm{O} \rightarrow \mathrm{C}$-glycoside rearrangements, see: (a) Matsumoto T, Katsuki M, Suzuki K. Tetrahedron Lett. 1988; 29:6935. (b) Matsumoto T, Katsuki M, Jona H, Suzuki K. J Am Chem Soc. 1991; 113:6982. (c) Ben A, Yamauchi T, Matsumoto T, Suzuki K. Synlett. 2004; 2:225.

ix. Brimble MA, Davey RM, McLeod MD, Murphy M. Aust J Chem. 2003; 56:787.

x. Bringmann G, Gotz R, Keller PA, Walter R, Boyd MR, Lang F, Garcia A, Walsh JJ, Tellitu I, Bhaskar V, Kelly TR. J Org Chem. 1998; 63:1090.

xi. Sajiki H, Hirota K. Tetrahedron. 1998; 54:13981.

xii. For examples, see: (a) Pflieger D, Muckensturm B. Tetrahedron Lett. 1990; 31:2299. (b) Anwar HF, Hansen TV. Org Lett. 2009; 11:587. [PubMed: 19105747]

xiii. O’Keefe BM, Simmons N, Martin SF. Org Lett. 2008; 10:5301. [PubMed: 18947231]

xiv. For examples, see: (a) Nicolaou KC, Mitchell HJ, van Delft FL, Rübsam F, Rodríguez RM. Angew Chem Int'l Ed. 1998; 37:1871. (b) Cutchins WW, McDonald FE. Org Lett. 2002; 4:749. [PubMed: 11869118]

xv. Thompson C, Ge M, Kahne D. J Am Chem Soc. 1999; 121:1237.

xvi. Hosoya T, Ohashi Y, Matsumoto T, Suzuki K. Tetrahedron Lett. 1996; 37:663.

xvii. Abe N, Enoki N, Nakakita Y, Uchida H, Nakamura T, Munekata M. J Antibiot. 1993; 46:692. [PubMed: 8501016]

xviii. Séquin U, Furukawa M. Tetrahedron. 1978; 34:3623. 
<smiles>C/C=C(\C)c1cc(=O)c2c(C)cc3c(OC)c4ccc(C5CC(N(C)C)[C@H](Oc6ccccc6)C(C)O5)c(O)c4c(OC)c3c2o1</smiles>
isokidamycin (2): $\mathrm{R}=-\mathrm{H}$

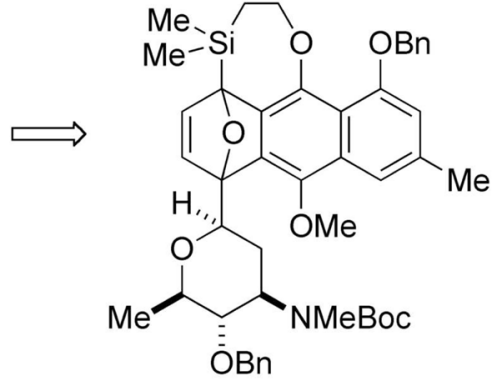

4<smiles>C=CCc1cc(OCCc2ccccc2)c2c(O)c(Br)c(Br)c(OC)c2c1</smiles>

6<smiles>C=CCc1ccccc1COc1c(Br)c(Br)c(OC)c2cc(C)cc(OCc3ccccc3)c12</smiles>

5<smiles>CC(=O)N[C@H]1C[C@H](c2ccc([Si](C)(C)CCO)o2)OC(C)[C@@H]1Cc1ccccc1</smiles>

7

Figure 1.

Retrosynthesis of kidamycin (1) and isokidamycin (2). 


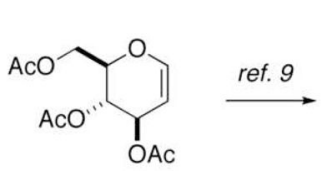

8

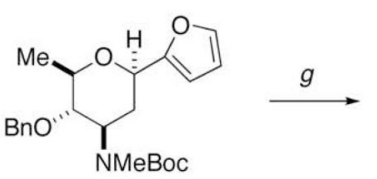

11

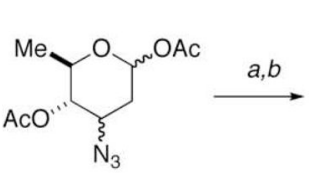

9

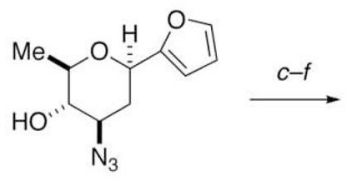

10

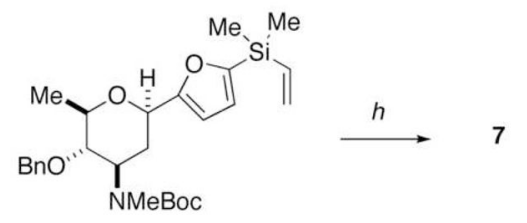

12

Scheme 1a.

${ }^{a}$ Reaction conditions: (a) $\mathrm{BF}_{3} \bullet \mathrm{OEt}_{2}$, furan, $\mathrm{MeCN}, 78 \%$; (b) $\mathrm{K}_{2} \mathrm{CO}_{3}, \mathrm{MeOH}, 60 \%$; (c) $\mathrm{BnBr}$, $\mathrm{NaH}, \mathrm{DMF}$; (d) $\mathrm{LiAlH}_{4}, \mathrm{Et}_{2} \mathrm{O}$; (e) $\mathrm{Boc}_{2} \mathrm{O}, \mathrm{CH}_{2} \mathrm{Cl}_{2}$; (f) $\mathrm{MeI}, \mathrm{NaH}, \mathrm{DMF}, 90 \%$ (4 steps); (g) $s$-BuLi, THF, $-78 \rightarrow-50{ }^{\circ} \mathrm{C}$; chlorodimethylvinylsilane, $-78{ }^{\circ} \mathrm{C}, 82 \%$; (h) 9-BBN, THF; $\mathrm{H}_{2} \mathrm{O}_{2}, \mathrm{NaOH}, 84 \%$. 


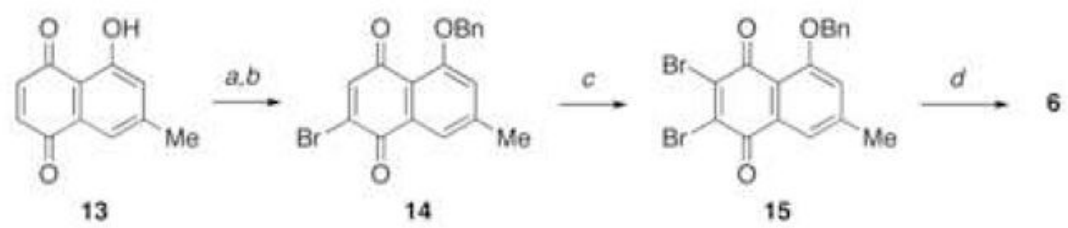

Scheme 2a.

${ }^{a}$ Reaction conditions: (a) $\mathrm{BnBr}, \mathrm{Ag}_{2} \mathrm{O}, \mathrm{CHCl}_{3}, 91 \%$; (b) $\mathrm{Br}_{2}, \mathrm{CH}_{2} \mathrm{Cl}_{2}$, then $\mathrm{NEt}_{3}, 97 \%$; (c) $\mathrm{PyHBr}_{3}, \mathrm{CH}_{2} \mathrm{Cl}_{2}, 0{ }^{\circ} \mathrm{C}, 90 \%$; (d) $\mathrm{Na}_{2} \mathrm{~S}_{2} \mathrm{O}_{4}, \mathrm{CH}_{2} \mathrm{Cl}_{2}, \mathrm{Et}_{2} \mathrm{O}, \mathrm{H}_{2} \mathrm{O} ; \mathrm{Me}_{3} \mathrm{OBF}_{4}$, proton sponge, $4 \AA$ molecular sieves, $\mathrm{CH}_{2} \mathrm{Cl}_{2}, 90 \%$. 


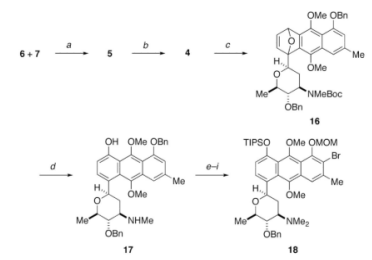

Scheme 3a.

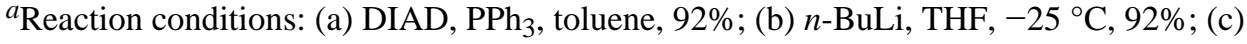
$\mathrm{TBAF} \cdot 3 \mathrm{H}_{2} \mathrm{O}$, DMF, $70{ }^{\circ} \mathrm{C}$; MeI, NaH, $0{ }^{\circ} \mathrm{C}$, 85\%; (d) TMSOTf, 2,6- $t \mathrm{Bu}_{2} \mathrm{Py}, \mathrm{CH}_{2} \mathrm{Cl}_{2}, 0{ }^{\circ} \mathrm{C}$ $\rightarrow \mathrm{rt}, 85 \%$; (e) formalin, $\mathrm{NaBH}(\mathrm{OAc})_{3}$, DCE, 95\%; (f) TIPSOTf, 2,6-lutidine, $\mathrm{CH}_{2} \mathrm{Cl}_{2}$, 80\%; (g) $\mathrm{H}_{2}, \mathrm{Pd}(\mathrm{OH})_{2} / \mathrm{C}$ (20 mol \%), pyridine, $\mathrm{MeOH}$, EtOAc, 90\%; (h) NBS, $\mathrm{CH}_{2} \mathrm{Cl}_{2},-78$ ${ }^{\circ} \mathrm{C} \rightarrow \mathrm{rt}, 77 \%$; (i) $\mathrm{MOMCl}, \mathrm{NaH}, \mathrm{THF}, 89 \%$. 
<smiles>C/C=C(\C)C#CC(=O)c1c(C)cc2c(OC)c3c([C@H]4CC(N(C)C)[C@H](Oc5ccccc5)[C@H](C)O4)ccc(OS)c3c(OC)c2c1OC</smiles>

\section{9}

Scheme 4a.

${ }^{a}$ Reaction conditions: (a) $n$-BuLi, THF, $-78^{\circ} \mathrm{C}, 20 \mathrm{~s}$; then $(E)$-4-methylhex-4-en-2-ynal (20), 75\%; (b) $\mathrm{BaMnO}_{4}, \mathrm{PhH}, 96 \%$; (c) $\mathrm{Et}_{2} \mathrm{NH}, \mathrm{EtOH},>99 \%$; (d) $\mathrm{LiBF}_{4}, 5 \%$ aq. $\mathrm{MeCN}, 82$ ${ }^{\circ} \mathrm{C}, \mu \mathrm{W}, 15 \mathrm{~min}$; TBAF, THF, $0{ }^{\circ} \mathrm{C}, 50 \%$. 

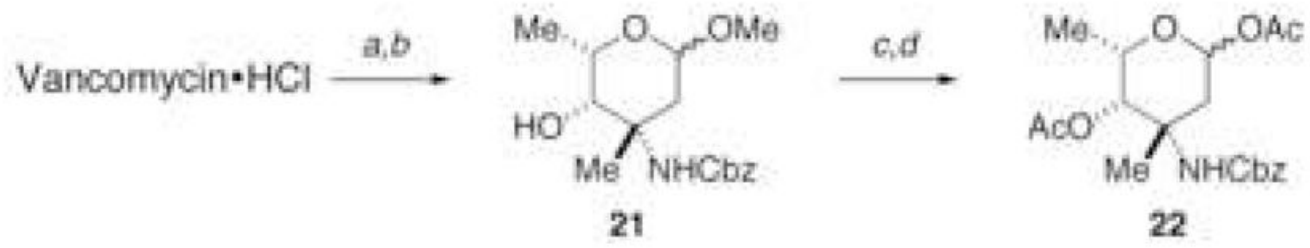

Scheme 5a.

a Reaction conditions: (a) Cbz-O-Succ, $\mathrm{NaHCO}_{3}$, dioxane, $\mathrm{H}_{2} \mathrm{O}$; (b) $\mathrm{HCl}, \mathrm{MeOH}, 89 \%$ (2 steps); (c) $\mathrm{HOAc}, \mathrm{H}_{2} \mathrm{O}, 100{ }^{\circ} \mathrm{C}, 71 \%$; (d) $\mathrm{Ac}_{2} \mathrm{O}$, pyridine, DMAP, $\mathrm{CH}_{2} \mathrm{Cl}_{2}, 85 \%$. 


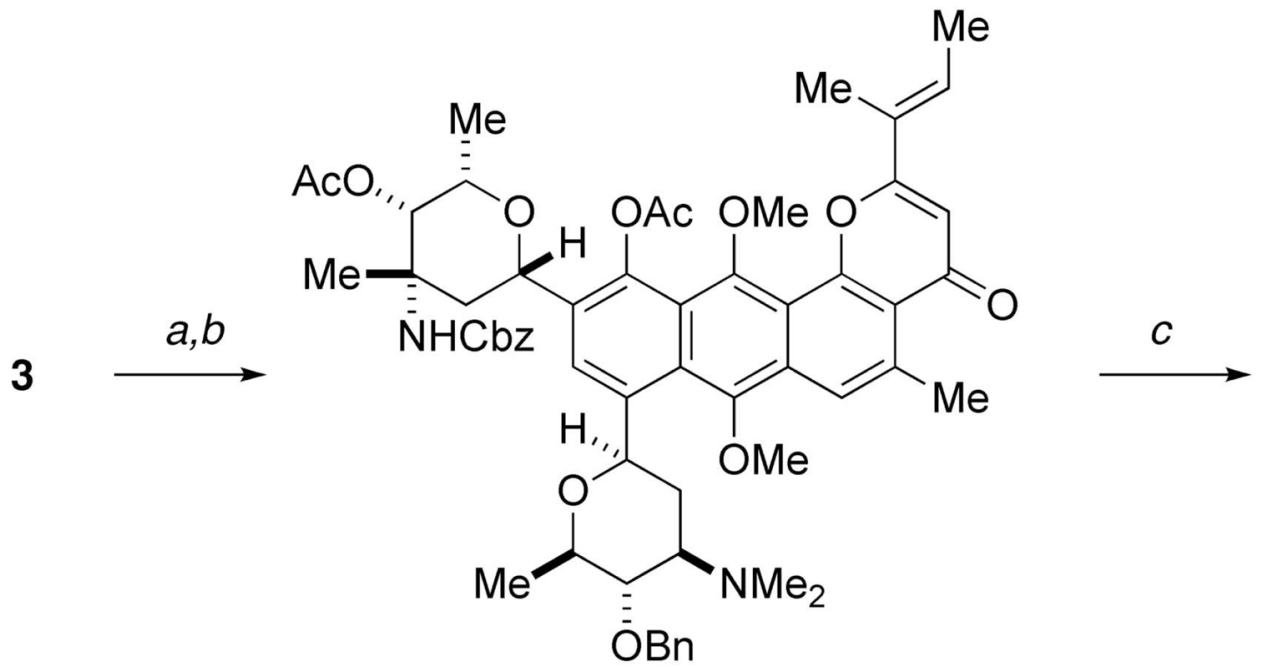

23<smiles>C/C=C(\C)c1cc(=O)c2c(C)cc3c(OC)c4c([C@H]5C[C@H](N(C)C)[C@@H](O)[C@H](C)O5)cc([C@H]5O[C@H](C)[C@@H](O)[C@](C)(N)C5(C)C)c(O)c4c(OC)c3c2o1</smiles>

24

Scheme 6a.

${ }^{a}$ Reaction conditions: (a) 22 (4 equiv), Sc(OTf) 3 , Drierite, DCE, $-30 \rightarrow 0{ }^{\circ} \mathrm{C}, 67 \mathrm{~h}, 80 \%$; (b) $\mathrm{Ac}_{2} \mathrm{O}$, pyridine, DMAP, $\mathrm{CH}_{2} \mathrm{Cl}_{2},>99 \%$; (c) $\mathrm{BBr}_{3}, \mathrm{CH}_{2} \mathrm{Cl}_{2},-90{ }^{\circ} \mathrm{C}$; TMSI, 2,6- $t \mathrm{Bu}_{2} \mathrm{Py}$, $\mathrm{CH}_{2} \mathrm{Cl}_{2},{ }^{\circ} \mathrm{C}$, then $\mathrm{MeOH}, \mathrm{pH}=7$ phosphate buffer; $\mathrm{NaCNBH}_{3}$, formalin, $\mathrm{HOAc}, \mathrm{MeOH}$, $\mathrm{CH}_{2} \mathrm{Cl}_{2} ; \mathrm{K}_{2} \mathrm{CO}_{3}, \mathrm{MeOH}, 3 \mathrm{~h}$; $\mathrm{MeOH}, 3 \mathrm{~d}, 39 \%$; (d) $\mathrm{Ce}\left(\mathrm{SO}_{4}\right)_{2}, \mathrm{MeCN}, \mathrm{H}_{2} \mathrm{O}(9: 1), 0^{\circ} \mathrm{C}, 51 \%$. 